\title{
Virological studies of sudden, unexplained infant deaths in Glasgow 1967-70
}

\author{
G. E. D. URQUHART ${ }^{1}$ AND N. R. GRIST \\ From the Viral Epidemiology Unit of the University Department of Infectious Diseases, Regtonal Virus \\ Laboratory, Ruchill Hospital, Glasgow
}

SYNOPSIS Virus isolation tests on 72 sudden unexplained infant deaths and 34 cases of explained death showed that 42 and $29 \%$ respectively had virus infections. A wide range of viruses was encountered, mainly enteroviruses and adenoviruses, mostly from bowel specimens. The findings did not suggest that overwhelming virus infection was a common feature of sudden death in infancy.

The cause of sudden, unexplained death in infancy is unknown, but respiratory infection due to viruses appears the most plausible hypothesis (Froggatt, Lynas, and Marshall, 1968). A study of cases in the Glasgow area was carried out to try to isolate 'newer' viruses, such as rhinoviruses and rubella, as well as those already looked for in previous studies.

\section{Materials and Methods}

Between April 1967 and September 1970 virus isolation procedures were carried out on postmortem specimens from 106 cases of explained and unexplained infant deaths, representing approximately $14 \%$ of the total deaths between the age of 1 and 12 months over this period in Glasgow. Specimens, collected approximately $\mathbf{3 2}$ hours after death (range 8-80 hours), included a tracheal swab, blood sample, pieces of lung, myocardium, brain (cerebral cortex plus midbrain), suprarenal fat, and a segment of large bowel. From the last 52 cases nasal swabs and thymus were also collected. Attempts were made to prevent cross contamination during collection and tissue specimens on arrival in the laboratory were rinsed six times in phosphate-buffered saline to remove any superficial contamination. Twenty per cent tissue extracts and $10 \%$ stool suspensions were made in phosphate-buffered saline with $1 \%$ bovine albumin. Swabs, tissue extracts, and blood cell deposits were inoculatied into secondary rhesus monkey kidney, W1 38 human diploid and Bristol HeLa tissue cultures, and incubated static at $37^{\circ} \mathrm{C}$. Respiratory tract specimens were inoculated in

'Present address: Public Health Laboratory, Gloucestershire Royal Hospital, Southgate Street, Gloucester.

Received for publication 9 November 1971. monkey kidney and W1 38 tissue cultures rolled at $33^{\circ} \mathrm{C}$ for myxovirus and rhinovirus isolation. All specimens were inoculated into newborn mice. Tracheal swabs from 63 cases were tested for rubella virus in RK13 cell cultures. Virus identification and serum neutralization tests were carried out as described by Grist, Ross, Bell, and Stott (1966). Respiratory syncytial virus antigen was also tested for by indirect immunofluorescence on lung impression smears in 27 cases during periods of prevalence of the virus in the community, and immunofluorescence tests for Coxsackie B1-6 virus antigens were carried out on cryostat cardiac sections in 13 cases.

\section{Results}

Of the 106 cases, $72(68 \%)$ occurred suddenly (history of mild symptoms less than $\mathbf{4 8}$ hours) and were unexplained macroscopically at necropsy examination (sudden unexplained death group), while in $34(32 \%)$ causes of death were found at postmortem examination (explained death group); six of the latter were sudden. The causes of death in the latter group were respiratory infection (10), gastrointestinal conditions (9), congenital abnormalities (9), and miscellaneous (eg, septicaemia, meningitis, etc) (6). The male :female ratio was $2: 1$ and $1: 8$ in the sudden unexplained death and explained death groups respectively; approximately $90 \%$ of infants in both groups were 6 months of age or less.

\section{Virus Isolations and Virus Groups}

Virus infections were demonstrated in 42 and $29 \%$ of the sudden, unexplained death and explained death groups respectively; three cases had dual infections 
(Table I). Approximately half the viruses were enteroviruses and one-third adenoviruses; there were four rhinovirus infections and one isolation each of parainfluenza type 1 and respiratory syncytial virus. No significant differences were observed between the sudden, unexplained death and explained death groups. No viruses were isolated in newborn mice or RK 13 cell cultures. One lung impression smear gave

\begin{tabular}{|c|c|c|c|}
\hline & \multicolumn{2}{|l|}{ Death } & \multirow[b]{2}{*}{ Total } \\
\hline & $\begin{array}{l}\text { Sudden } \\
\text { Unexpected }\end{array}$ & Explained & \\
\hline Cases tested & 72 & 34 & 106 \\
\hline Isolations from bowel & 23 & 6 & $29^{1}$ \\
\hline $\begin{array}{l}\text { Isolations from upper } \\
\text { respiratory tract }\end{array}$ & 9 & 3 & $12^{2}$ \\
\hline $\begin{array}{l}\text { Isolations from tissue and/or } \\
\text { blood }^{3}\end{array}$ & 10 & 3 & 13 \\
\hline
\end{tabular}

Table II Virus isolations from different sources

${ }^{1}$ Twenty-three isolations from bowel alone (see Table IV)

'Seven isolations from upper respiratory tract alone (see Table IV).

${ }^{3}$ Virus isolations also from bowel and/or upper respiratory tract in nine cases (see Table III). a positive test for respiratory syncytial virus antigen and the virus was isolated from the corresponding lung extract (Table I). No Coxsackie B virus antigens were detected in cardiac sections of 13 cases.

\section{Sources of Virus and Virus Types}

Tables II and III show the sources of virus isolations. Most isolations were from superficial sites, particularly bowel $(27 \%$ specimens positive), but with no significant difference between sudden, unexplained death and explained death groups. Of the 13 with virus isolation from tissue and/or blood, Table III shows that similar viruses were isolated from the bowel and/or upper respiratory tract of nine, in six of which virus titres in the latter specimens exceeded titres (as judged by time for cytopathic effects to appear in tissue cultures) in the other specimens. The two cases of rhinoviraemia were reported in detail elsewhere (Urquhart and Stott, 1970). The virus types encountered were varied (Tables III and IV). Suprarenal fat gave the highest yield of virus from an

\begin{tabular}{|c|c|c|c|c|c|c|c|c|c|c|}
\hline \multirow[t]{2}{*}{ Type of Death } & \multirow[t]{2}{*}{ Virus Isolated } & \multicolumn{9}{|c|}{ Days to Produce Cytopathic Effect in Tissue Cultures Inoculated with Indicated Specimen } \\
\hline & & $\boldsymbol{B}$ & $T$ & $N$ & $L$ & $M$ & $B R$ & $S$ & $B C$ & $B S$ \\
\hline Sudden unexpected & Aaeno 1 & $-{ }^{3}$ & 5 & $\mathrm{NT}^{3}$ & 5 & - & - & - & - & NT \\
\hline Sudden unexpected & Adeno 2 & 17 & 5 & NT & 24 & 24 & 19 & 24 & 13 & 8 \\
\hline Sudden unexpected & Adeno 2 & 3 & - & NT & - & - & - & 18 & 7 & NT \\
\hline Sudden unexpected & Adeno 5 & 7 & 7 & NT & 22 & 13 & 28 & 13 & - & NT \\
\hline Sudden unexpected & Echo 14 & 4 & - & - & - & - & - & 11 & - & - \\
\hline Sudden unexpected & Echo 15 & - & - & NT & - & - & - & 26 & - & NT \\
\hline Sudden unexpected & Cox B3 & - & - & NT & - & - & - & 8 & - & NT \\
\hline Sudden unexpected & Ent $^{2}$ & 11 & - & NT & - & - & 一 & 18 & - & NT \\
\hline Sudden unexpected & Rhino 15 & - & 8 & NT & - & 一 & - & - & 7 & 3 \\
\hline Sudden unexpected & Rhino 22 & - & - & 8 & - & - & - & - & 一 & 3 \\
\hline Explained & Echo 3 & - & - & NT & - & - & - & - & 12 & NT \\
\hline Explained & Echo 20 & 4 & 一 & NT & - & - & - & 21 & - & NT \\
\hline Explained & RS Virus & - & - & 一 & 21 & - & NT & - & - & NT \\
\hline
\end{tabular}

Table III Virus isolations from organs or blood in 13 infant deaths

${ }^{1} \mathbf{B}=$ bowel; $\mathbf{T}=$ tracheal swab; $\mathbf{N}=$ nasal swab; $\mathbf{I}=$ lung; $\mathbf{M}=$ myocardium; $\mathbf{B R}=$ brain; $\mathbf{S}=$ suprarenal fat; $\mathbf{B C}=$ blood cell deposit; BS = serum.

${ }^{2} \mathrm{Ent}=$ enterovirus, type not identified

._. no virus isolated; NT $=$ not tested. 


\begin{tabular}{|c|c|c|c|c|c|}
\hline \multirow[t]{3}{*}{ Virus } & \multicolumn{4}{|l|}{ Number of Isolations } & \multirow[t]{3}{*}{ Total } \\
\hline & \multicolumn{2}{|l|}{ Bowel } & \multicolumn{2}{|c|}{ Upper Respiratory Tract } & \\
\hline & $\begin{array}{l}\text { Sudden Unexpected } \\
\text { Death }\end{array}$ & $\begin{array}{l}\text { Explained } \\
\text { Death }\end{array}$ & $\begin{array}{l}\text { Sudden Unexpected } \\
\text { Death }\end{array}$ & $\begin{array}{l}\text { Explained } \\
\text { Death }\end{array}$ & \\
\hline Adenovirus $^{1}$ & 5 & $4^{3}$ & $2^{3}$ & 0 & 11 \\
\hline Echovirus $^{2}$ & 6 & 1 & 0 & 1 & 8 \\
\hline Coxsackie A9 & $1^{3}$ & 0 & 0 & 0 & 1 \\
\hline Coxsackie B2 & 1 & 0 & $\mathbf{0}$ & 0 & 1 \\
\hline Coxsackie B3 & 3 & 0 & 1 & 0 & 4 \\
\hline Poliovirus & $2^{3}$ & 0 & 0 & 0 & 2 \\
\hline Rhinovirus & NT & NT & 1 & 1 & 2 \\
\hline Parainfluenza 1 & NT & NT & 0 & $1^{3}$ & 1 \\
\hline Total & 18 & 5 & 4 & 3 & 30 \\
\hline
\end{tabular}

Table IV Viruses isolated from bowel or upper respiratory tract only

IIncludes types 1, 2, 5, 7, 9, 15 and untyped.

${ }^{2}$ Includes types 1, 7, 8, 12, 14, 19, 22.

NT $=$ not tested

'Double infections: Coxsackie A9 (bowel) + adeno 5 (upper respiratory tract); poliovirus type $2+3$ isolated; parainfluenza 1 (upper respiratory tract) + adeno 9 (bowel).

internal site (8/13 positive), followed by blood (5/13) and lung (4/13). Thymus extracts in 52 cases failed to yield virus.

\section{Relationship to Community Viruses}

Comparison of faecal virus carriage in 27 sudden, unexplained death cases and 27 healthy control infants (Table V), matched for time of sampling, age, sex, social class, siblings, and residential area, showed that control infants excreted twice as many viruses. This difference was not significant.

\begin{tabular}{lll}
\hline & \multicolumn{2}{l}{ Category } \\
\cline { 2 - 3 } & Sudden Unexplained Death & Control \\
\hline No. tested & 27 & 27 \\
No. positive (\%) & $5(19)$ & $10(37)$ \\
Adenovirus $^{1}$ & 0 & 2 \\
Echovirus $^{2}$ & 3 & 2 \\
Coxsackie A9 $_{\text {Coxsackie B2 }}$ & 1 & 1 \\
Poliovirus $^{2}$ & 1 & 2 \\
\hline
\end{tabular}

Table $\mathrm{V}$ Bowel virus isolations from cases of sudden, unexpected death and matched healthy controls

'Includes type 5 and untyped.

'Includes type 6, 9, 12, 14 and 22.

'Includes type 3 and $1+2$ mixed.

The viruses isolated from infant death cases were similar to viruses isolated from cases of illness in the community requiring hospital admission over the same period, but many viruses known to be present in the general community were not isolated from the death cases: these were rubella, cytomegalovirus, herpes simplex, and influenza $\mathbf{A}_{2}$. There was no apparent relationship between causes of death and virus isolations in the explained death group.

\section{Other Studies}

Serum neutralization tests using homologous virus showed that $13 / 29$ sudden, unexplained death cases and five of nine explained death cases possessed varying levels of neutralizing antibody, similar in both groups.

Quantitative studies revealed no difference beween the titres of bowel virus in healthy infants and sudden, unexplained death cases.

\section{Discussion}

Although this investigation provided a higher virus isolation rate for a larger number of sudden deaths than other published surveys of which we are aware (Balduzzi and Greendyke, 1966; Valdes-Dapena, 1967; O'Reilly and Whiley, 1967; Ray, Beckwith, Hebestreit, and Bergham, 1970), the types of virus found were commonplace and correspond to those known to be active in the community at the same time (with notable absences of rubella and influenza). The prevalence and types of virus were similar in the sudden, unexplained death and explained death cases, and were also similar for faecal viruses isolated from sudden, unexplained death and matched healthy control infants. Congenital or neonatal infection with rubella or cytomegalovirus might conceivably be a factor in sudden death, but neither was detected. The scarcity of myxovirus isolates might be attributable to delay before sampling after death or to the small numbers examined during 
winters (about 12 per winter), but the single isolation of the labile respiratory syncytial virus was from a sample taken as late as 60 hours after an explained death, in agreement with detection of respiratory syncytial virus antigen by immunofluorescence in lung impression smears from this infant. In contrast with the findings of Burch, Sun, Colcolough, Sohal, and de Pasquale (1967) in Louisiana, Coxsackie B antigen was not detected by immunofluorescence in cryostat sections of hearts.

Most virus isolations were from "superficial" (alimentary or upper respiratory) rather than from deep (blood or tissue) sites. The titres tended to be higher in samples from the superficial sites, and the significance of 'deep' isolates is difficult to evaluate without controls which are obviously very difficult to obtain. The presence of virus in tissue does not necessarily have clinical significance and indeed may commonly follow viraemia which is a feature of many virus infections. The high proportion of isolates from suprarenal fat specimens may be due to their content of brown fat which, as in some animals, may be a specially favourable site for virus multiplication and persistence (Grist and Roberts, 1966; Afzelius, 1970).

Our findings do not suggest the presence of overwhelming virus infection, particularly of the respiratory tract, as a common feature of sudden, unexplained death. Like others we found a wide range of virus infections. Our investigation did not extend to bacterial infections which have not been clearly incriminated by other workers (Valdes-Dafsna, 1966). The possible relevance of the highly prevalent virus infections to sudden death in infancy may depend on their participation in an immunological process leading to death, and some evidence for this has been published in this journal (Urquhart, Logan, and Izatt, 1971).

We thank the pathologists for permission to sample their cases, our laboratory colleagues, and the staff of the Glasgow Department of Maternity and Social Welfare, Miss R. McDaid and Mr G. Davie for technical assistance, and the Medical Research Council for a grant.

\section{References}

Afzelius, B. A. (1970). Brown adipose tissue in infections. In Brown Adipose Tissue, edited by O. Lindberg, p. 27. American Elsevier. New York.

Balduzzi, P. C., and Greendyke, R. M. (1966). Sudden unexpected death in infancy and viral infection. Pediatrics, 38, 201-206.

Burch, G. E., Sun, S. C., Colcolough, H. L., Sohal, R. S., and de Pasquale, W. P. (1967). Coxsackie virus valvulitis and myocarditis observed at routine autopsy. Experientia (Basel), 23. 1041-1042.

Froggatt, P., Lynas, M. A., and Marshall, T. K. (1968). Sudden death in babies: epidemiology. Amer. J. Cardiol., 22, 457-468.

Grist, N. R., and Roberts, G. B. S. (1966). Coxsackie A7 virus infections of rodents. Arch. ges. Virusforsch., 19, 454-463.

Grist, N. R., Ross, C. A. C., Bell, E J., and Stott, E. J. (1966) . Diagnostic Methods in Clinical Virology. Blackwell, Oxford.

O'Reilly, M. J. J., and Whiley, M. K. (1967). Cot deaths in Brisbane 1962-66. Med. J. Aust., 2, 1084-1087.

Ray, C. G., Beckwith, J. B., Hebestreit, N. M., and Bergham, A. B. (1970). Studies of the sudden infant death-syndrome in King County, Washington. I. The role of viruses, J. Amer. med. Ass., 211, 619-623.

Urquhart, G. E. D., Logan, R. W., and Izatt, M. M. (1971). Sudden unexplained death in infancy and hyperimmunization. J. clin. Path., 24, 736-739.

Urquhart, G. E. D., and Stott, E. J. (1970). Rhinoviraemia. Brit, med. $J ., 4,28-30$.

Valdes-Dapena, M. A. (1967). Sudden and unexpected death in infancy: a review of the world literature, 1954-66. Pediatric: 39, $123-138$ 